\title{
The Impact of Mobile Device Use on Shopper Behaviour in Store: An Empirical Research on Grocery Retailing
}

\author{
Silvia Bellini ${ }^{1}$, Simone Aiolfi ${ }^{2}$ \\ ${ }^{1}$ Department of Economics, University of Parma, Italy \\ ${ }^{2}$ Department of Economics, University of Ferrara, Italy \\ Correspondence: Silvia Bellini, Department of Economics, University of Parma, Italy.
}

\author{
Received: February 14, 2017 \\ Accepted: March 3, 2017 \\ Online Published: March 8, 2017 \\ doi:10.5539/ibr.v10n4p58 \\ URL: https://doi.org/10.5539/ibr.v10n4p58
}

\begin{abstract}
Over the last decade, retailers and manufacturers alike are increasing their attention to the role of instore mobile technology use with the aim to understand its impact on consumers' decision making process. The rise of the mobile channel, in fact, has produced disruptive changes in shopping habits designed to gradually reduce the effectiveness of in-store marketing levers in influencing shopping behaviour.

This topic is of paramount importance in grocery sector since retailers and manufacturers devote a lot of investments in instore marketing activities with the aim to influence consumers' decisions and stimulate impulse purchases. Nevertheless, there are few contributions about the influence of the mobile technology in a retail setting and its effects on buying behavior inside the store.

Our research intends to explore the impact of in-store mobile technology use on shopper behavior instore in order to understand its effects on planned versus unplanned purchases. According to our preliminary results, consumers using mobile technology instore make less unplanned items and fail to purchase more planned items. Moreover, the use of mobile technology negatively impacts shoppers' ability to recall in-store stimuli. Our findings are interesting for both retailers and manufacturers who are looking for new ways to better address their marketing efforts and increase consumers' engagement instore.
\end{abstract}

Keywords: mobile devices, in-store stimuli, unplanned purchases, shopping behavior, grocery retailing

\section{Introduction}

The growing penetration of mobile devices has significantly altered consumers' behavior and generally the way we live and work. From a simple communication device, developments in smartphone technology have changed consumers' lives, and not always for the better. Smartphone dependence has become a global phenomenon, particularly in Italy. According to a recent research (Global Mobile Consumer Survey, 2015), Italians are the first in Europe for using their mobile phone while spending time with family or friends $(74 \%)$, when in a business meeting (42\%) and while driving (31\%). Millions of Italian consumers check their smartphones constantly, day and night. They wake to the sound of their phone alarms, use them to check news and notifications. Indeed, Italians are the first in Europe for doing so even without having heard their phones ring: $68 \%$ of Italians admit to check their phone unprompted by a notification. Finally, Italy is the European country with the highest number of users that connect to the internet through their mobile network allowance rather than through Wi-Fi.

Digitalization has significantly impacted the business landscape and managers have become interested in designing new strategies that could improve their profitability by taking advantage of technological innovations (Riasi and Pourmiri, 2015). One of the most appealing targets for marketing managers is the customers' decision making process in the digital world (Ansari and Riasi, 2016).

The widespread mobile connectivity and the gradual development of new technology have not only changed the way we interact and communicate, but have significantly impacted on consumer decision-making process. Consumers in a retail setting use this tool with different purposes: finding information on the web, comparing pricing and purchasing goods and services (Bellini, Cardinali \& Grandi, 2016). Therefore it becomes crucial to understand how the mobile influences the decision-making process as well as the buying behavior of shoppers. The growing penetration of mobile devices has provided firms with an unprecedented opportunity to engage consumers but to know how to take advantages from this tool it is important to investigate the impact of mobile 
devices on consumer outcomes. Manufacturers and retailers are worried that the mobile could potentially distract the customer from the products and services offered within the store.

The analysis of the factors influencing the consumer's decision making process inside the store has always interested researchers (Kollat \& Willet, 1967; Iyer \& Ahlawat, 1987; Iyer, 1989; Donovan, Rossiter, Marcoolyn \& Nesdale, 1994; Inman, Winer \& Ferraro, 2009; Mohan, Sivakumaran \& Sharma, 2013; Shankar, 2014; Bellini et al., 2016). Nevertheless, the impact and the role of mobile technologies, such as smartphones and other mobile devices, is a subject still little explored. Along with the modernization of the retail system and the increasingly important role played by retailers in terms of consumer choices, the knowledge and analysis of what influences the shopper inside the store and how to increase demand for their product/service and brands are fundamental questions both for retailers and manufactures. The presence or absence of the shopping list and its form are variables that affect further on consumer behavior within the store, determining the amount of planned and impulse purchases (Block \& Morwitz, 1999). While the first are products that consumers plan to buy before entering the store, the second type defines unplanned purchases, which arise inside the store, determined by one or more stimuli (Beatty \& Ferrell, 1998).

Our research aims to investigate the influence of in-store mobile technology use on consumers' purchase behavior in order to understand its effects on the marketing stimuli produced by the retailer inside the store. Our findings will suggest retailers and manufacturers new ways to capture the attention of consumers and increase the involvement of the consumer inside the store in order to better address their marketing efforts.

The paper is organized as follows. First, a literature review about decision-making process and mobile use in grocery retailing is presented (par. 2). Secondly, we present our hypotheses (par. 3) and the methodology used (par. 4). Then, we present and discuss our findings (par. 5). Finally, the last two sections are devoted to conclusion and managerial implications (par. 6), limitations and future direction (par. 7).

\section{Theoretical Framework}

\subsection{Decision-making Process and Mobile Use}

Mobile technologies can reduce search cost and improve the quality of consumer choice (Haubl \& Trifts, 2000; Murray \& Haubl 2008). Despite the positive expectations, in many cases research acknowledges that these devices can create unintended consequences and damage the lives of individuals in terms of visual and cognitive impairments (Strayer \& Johnston, 2001; Strayer, Drews \& Johnston, 2003). In particular, previous researches identify the dangerous consequences of mobile technology use while driving, discovering that people simultaneously using or conversing on a smartphone and driving a vehicle miss twice as many traffic signals as people not using a phone. (Brookhuis, Karel, De Vries \& De Waard, 1991; Briem and Hedman, 1995; Strayer \& Johnston, 2001; Strayer et al., 2003; Drews, Pasupathi \& Strayer, 2008).

These results are consistent with psychological theories, that identify the attentional capacity as well as attentional limitations of individuals' mental system dealing with simultaneous tasks (Welford \& Traviss, 1952; Broadbent, 1958; Kahneman, 1973; Norman \& Bobrow, 1975; Navon \& Gophers, 1980; Fagot \& Pashler, 1992; Pashler \& Johnston, 1998) and the conceptualization of distraction as the act of diverting or directing attentional resources from a focal object to another (source of distraction) or apportioning attentional resources in multiple directions (Strayer \& Johnston, 2001; Lavie, Hirst, De Fockert \& Viding, 2004; Lavie, 2005; Inman \& Sciandra, 2013).

Mobile use has attracted not only the greatest media interest, but also the interest of marketing scholars conscious about the effect of the widespread mobile connectivity on consumer decision-making process. Mobile technologies have been considered a resource for helping consumers make better decisions (Sciandra, 2014).

The decision making process is a complex and long path characterized by different stages which take place both in and out of store (Puccinelli et al., 2009): it starts when consumer's needs emerge, goes on with information seeking and evaluation of different alternatives and ends up with purchase decision and post-purchase considerations.

In a retail environment, mobile devices and new applications for smartphones allow shoppers to scan product barcodes, compare prices across retailers or obtain digital coupons to be redeemed in store. The usage of technologies in pre-shopping phase could help shoppers to make better decision and being less influenced by the environment while expending less effort inside the store (Bellini et al., 2016). Therefore, digital tools may have positive effects on both the quality and the efficiency of purchase decisions inside the store. 


\subsection{Decision-making Process and Mobile Use in Grocery Retailing: How Mobile Influences Pre-shopping Preparation}

Starting from the 90 's, several authors have started to investigate the role of the point of sale in consumers' decisions (Hirshman \& Holbrook, 1982; Bucklin \& Lattin, 1991; Donovan et al., 1994; Beatty \& Ferrel, 1998; Bell, Corsten \& Knox, 2011) on the belief that it was possible to stimulate purchases not planned before towards profitable products and/or categories (Inman et al., 2009). Shoppers recognize the ability of retailers to generate immediate desires and they try to limit this effect by activating some "self-control strategies", which are strategies oriented to control impulsiveness in order to be less conditioned by instore stimuli (Hoch \& Loewenstein, 1991; Cheema \& Soman, 2006).

The tendency of self-regulation is emphasized by the growing penetration of digital technology, which enables consumers to prepare the shopping expedition with different tools: digital shopping list, on-line price comparison, consultation of digital flyers and usage of apps. In particular, the diffusion of mobile devices has enabled consumers to search for product and pricing information anywhere at any time, both outside and inside the store (Silveira \& Marreiros, 2014). As a consequence, consumers today enter the store much more prepared than in the past, and they are able to shop quickly only looking for products they had planned to buy (Bellini et al., 2016). The degree of grocery shopping preparation is found to influence shopper behaviour inside the store in terms of planned/impulse buying: the higher is the degree of preparation, the greater is the tendency to plan purchases and the lower is the tendency to make impulse purchases (Bellini et al., 2016). To conclude, the usage of technologies during the pre-shopping phase could help shoppers to make better decision and being less influenced by the environment while expending less effort inside the store. Such trends are designed to influence shopping behavior instore in terms of planned vs unplanned purchases (Bellini, Cardinali \& Grandi, 2017).

2.3 Decision-making Process and Mobile Use in Grocery Retailing: How Mobile Influences Shopping Behavior Instore

Concerning with the retail setting, the distraction caused by mobile might make invisible some of the products within the store, leading to a less efficient communication and therefore to fewer impulse purchases. The role that mobile devices play in consumer decisions in a retail setting is an extremely interesting area but less unexplored yet.

The role of the mobile may be different depending on the type of use that is done. In particular, we can identify two different categories: a use related to the task you are doing and, conversely, a use that is unrelated to the task (Sciandra \& Inman, 2014). According to this classification, we can investigate the effects of the mobile technology in relation to the situation, as well as to the decision that the individual must take. In the perspective of the consumers within a retail setting, the task that the consumers need to do is to complete their shopping expedition, observing a precompiled shopping list, if any. Using this categorization, we can identify when shoppers use mobile in a way connected to shopping and when they use it for other activities and, consequently, to study the effects that occur in either case.

According to Sciandra \& Inman (2014), task-unrelated mobile device use occurs when a consumer uses the mobile device in a manner that is not directly related to the focal decision task and includes uses such as engaging in private conversations, sending personal text messages, checking emails, and surfing the Internet. Conversely, task-related mobile device use occurs when a consumer uses the mobile device in a manner that is directly related to the focal decision task. Task-related device use is becoming particularly important in retail environments and includes uses such as comparing prices, accessing digital shopping lists, using mobile shopping applications, and calling someone for help with a decision.

One of the biggest differences between task-related and task-unrelated mobile device use is that consumers' expenditure of cognitive resources during task-related use is directly related to the decision task. Shoppers using devices in a shopping-related manner may better provided to track items or to evaluate spending. The amount remaining in the budget during a shopping expedition influences consumer decision making and spending (Stilley, Karen, Inman \& Wakefield, 2010). As a consequence, consumers who perceive a budgetary surplus make more unplanned purchases (Beatty \& Ferrell, 1998).

If consumers use mobile technology in a shopping-related manner, they are able to track unplanned purchases and continuously update their budgetary figure to stay within intended spending limits. So the use of mobile phones related to shopping has the potential to help the consumer during the purchase making process. In this way, the shopper is able to identify the best substitute products over products which had planned the purchase and to avoid buying additional products not previously planned. When consumers use the mobile in a way that is not related to the shopping task, they will be more distracted and so the use of mobile will have a negative 
impact on individual decision-making process. The mobile distraction can indeed hinder the processing of information and consumer decision-making that might easily fail to purchase planned items, together with the fact that the shopper will be less influenced by the in-store communication of retailers that will therefore be less effective (Inman \& Sciandra, 2013).

\section{Research Aims and Hypotheses}

Our study aims to gather more information on the effects of instore mobile technologies use on shopper's purchasing behavior in Italy, which is the European country with the highest penetration of the mobile devices. We suppose that the growing usage of mobile technology during the shopping expedition could distract consumers who risk losing their attention towards marketing stimuli instore. As a consequence, instore marketing activities (promotions, extra displays, communications, extra activities, etc.) might become less effectiveness in stimulating unplanned purchases.

Previous research stated the key role that in-store stimuli and displays play in influencing shoppers (Inman et al., 2009; Stilley et al., 2010; Inman \& Sciandra, 2013), acknowledge the impact that technological distraction can have on individuals' visual attention and state the distractive nature of mobile technologies, resulting in shoppers missing in-store cues (Strayer et al., 2003; Hyman et al., 2010; Inman \& Sciandra, 2013). According to these findings, we state our first hypotheses:

H1: Consumers using mobile devices in store will be less able to recall marketing stimuli produced by retailers in the retail setting, compared to consumers not using mobile devices.

The impact of mobile devices on the effectiveness of instore communication could lead fewer unplanned purchases. These effects, however, could be different depending on the connection between the mobile and the shopping activity. In line with prior research (Sciandra \& Inmann, 2014), we made a distinction between consumers using mobile technology in a shopping related manner and consumers using mobile devices for shopping-unrelated use. We argue that shoppers using mobile device, both in a related and unrelated manner, will make fewer unplanned purchases compared to consumers not using mobile devices but for different reasons due to the different purchase and decision making model behind them. When used in a task-unrelated manner, shoppers will make fewer unplanned purchases because they are more distracted and they give less attention towards instore stimuli. When used in a task-related manner, shoppers will make fewer unplanned purchases because they are better equipped to stay on track during the shopping trip. Compared to consumers using mobile in a shopping unrelated manner, we expect that they will make more unplanned purchases due to the fact that they are able to identify more attractive alternatives for shopping. So, the number of unplanned purchases is a result of a conscious decision due to the fact that the mobile device is enriching the decision making process.

These considerations lead to the following hypothesis:

H2: Consumers using mobile technologies in a shopping-unrelated manner will be more distracted during the shopping trip and they will make fewer unplanned purchases compared to consumers not using mobile devices or using mobile devices in a shopping-related manner.

H3: Consumers using mobile technologies in a shopping-related manner will be better equipped to stay on track during the shopping trip and they will make fewer unplanned purchases compared to consumers not using mobile devices.

Mobile device use will impact unplanned purchases, but in-store mobile technology use may influence planned purchases as well. Specifically, it was stated that shopping-unrelated use may change shoppers' decisions related to planned items altering the number of items planned but not purchased. As a result, the shoppers will fail to purchase more planned items and could spend less than what they expected. On the contrary, shoppers using their devices in a shopping-related manner are in a better position to identify less expensive or more attractive alternatives for planned items because the mobile device is acting as an additional tool to aid in decision making (Sciandra \& Inmann, 2014). Hence, these shoppers are more likely to move away from a planned item to a superior alternative and may delay a planned purchase if a more attractive price or item is found through a different channel, for example online or at a different retailer. So, considering shoppers using their device in a shopping-related manner we could state that the number of planned but not purchased items is due simply to the fact that their mobile device is enriching the decision making process. These considerations lead to our final hypotheses.

H4 - Consumers using mobile technologies in a shopping-unrelated manner, will be more distracted and they will have a great number of planned but not purchased items in their shopping list compared to consumers not using mobile devices or using a mobile device in a shopping-related manner. 


\section{Methodology}

To test these hypotheses, we used a single-stage mall-intercept survey method to collect data using a process similar to previous studies (Beatty \& Ferrell, 1998; Sharma, Sivakumaran \& Marshall, 2010; Mohan \& Sharma, 2013, Sciandra \& Inmann 2014). A leading Italian grocery retailer gave us the permission to conduct our survey in its stores. We selected the hypermarket store format assuming that, given its big sales area, people spend more time inside and there could be a higher probability of using the mobile. Moreover, considering the variety of the range and promotions, we can assume that shoppers are more likely use their smartphone to compare prices and search for information about products or promotions.

Shoppers were intercepted after the checkout and requested to answer to a structured questionnaire. A total of 112 shoppers were interviewed, but 28 individuals were then excluded because they did not have a written or digital shopping list. Consequently, our sample was composed of 84 individuals: $86 \%$ of them had a printed list while the remaining $14 \%$ had a digital list. Table 1 illustrates the demographics characteristic of the sample.

Table 1. Demographics characteristic of the sample

\begin{tabular}{|c|c|c|c|c|c|c|c|}
\hline \multirow{2}{*}{\multicolumn{3}{|c|}{ Statistics }} & \multicolumn{4}{|c|}{ Age group } & \multirow[b]{2}{*}{ Total } \\
\hline & & & $18-35$ & $36-55$ & $56-65$ & Over 65 & \\
\hline \multirow{6}{*}{ Gender } & Women & Count & 28 & 22 & 10 & 1 & 61 \\
\hline & & $\%$ within Gender & $45.9 \%$ & $36.1 \%$ & $16.4 \%$ & $1.6 \%$ & $100 \%$ \\
\hline & & $\%$ within Age group & $77.8 \%$ & $75.9 \%$ & $55.6 \%$ & $100 \%$ & $72.6 \%$ \\
\hline & Men & Count & 8 & 7 & 8 & 0 & 23 \\
\hline & & $\%$ within Gender & $34.8 \%$ & $30.4 \%$ & $34.8 \%$ & $0 \%$ & $100 \%$ \\
\hline & & $\%$ within Age group & $22.2 \%$ & $24.1 \%$ & $44.4 \%$ & $0 \%$ & $27.4 \%$ \\
\hline \multirow[t]{3}{*}{ Total } & & Count & 36 & 29 & 18 & 1 & 84 \\
\hline & & $\%$ within Gender & $42.9 \%$ & $34.5 \%$ & $21.4 \%$ & $1.2 \%$ & $100 \%$ \\
\hline & & $\%$ within Age group & $100 \%$ & $100 \%$ & $100 \%$ & $100 \%$ & $100 \%$ \\
\hline
\end{tabular}

According to previous research (Sciandra \& Inmann, 2014) we first classified the mobile technology use. We indicated a shopping-related usage if the respondents indicated they used their phone to compare prices of products, to create or access a shopping list, to compare different retailers for the best price, to look at a retailer's website or at a manufacturer's website, to scan a QR code on a package, and/or to call someone for help with a decision. Mobile technology use, instead, was classified as shopping-unrelated if the respondents indicated they used their phone to make or receive calls, to send and reply to personal messages, to control their social networks, to check or send emails, to look at websites not related to the shopping trip, to listen to music, and/or to play.

As shows in Table 2, 28.6\% of the respondents used the phone while shopping, while $71.4 \%$ did not used it.

Table 2. Mobile usage during the shopping expedition

\begin{tabular}{llcc}
\hline & & \multicolumn{2}{c}{ Mobile usage during the Shopping expedition } \\
\cline { 2 - 4 } & & No & Yes \\
\hline Gender & Women & $72.1 \%$ & $27.9 \%$ \\
& Men & $69.6 \%$ & $30.4 \%$ \\
\hline Total & & $\mathbf{7 1 . 4 \%}$ & $\mathbf{2 8 . 6 \%}$ \\
\hline
\end{tabular}

In detail, most of the shoppers, $70.8 \%$ of the total, uses the mobile device for activities not related to shopping, such as to make or receive personal calls, send or read messages or to check social networks. On the contrary, the remaining $29.2 \%$ employs mobile for a use related to the shopping experience, especially to watch the shopping list, to count, to control prices and promotions, or seek alternatives (see Table 3).

Table 3. Mobile usage in store

\begin{tabular}{lr}
\hline USE & PERCENT \\
\hline Shopping-Related & $\mathbf{2 9 . 2 \%}$ \\
\hline To look for information and product recommendations & $12.5 \%$ \\
To look for information about promotions & $8.3 \%$ \\
To watch the shopping list & $4.2 \%$ \\
To make calculations & $4.2 \%$ \\
\hline Shopping-Unrelated & $\mathbf{7 0 . 8 \%}$ \\
\hline To answer or make private phone calls & $49.9 \%$ \\
To answer or send personal messages & $16.7 \%$ \\
To check the social networks & $4.2 \%$ \\
\hline
\end{tabular}

The interview focused on the stimuli produced within the store, trying to figure out whether there was a relationship between mobile usage and the memory of product promotions and advertisements displayed in the store, as well as the presence or absence of promoters. So, we investigated the number of products that consumers can call to mind, considering both products in promotion and advertised by the promoters. 
Finally, it was required to customers the shopping list, if any, and the ticket, in order to identify which products they had planned to purchase, which ones they had missed and which they had purchases impulsiveness. In this way it was possible to calculate the difference between the number of products that they had planned to purchase but that have not been purchased and the number of excess products present in the basket in relation to the shopping list (unplanned purchases). According to Sciandra \& Inmann (2014), we built two variables: the number of unplanned purchases, operationalized as the total number of items that were purchased by the shopper but were not planned prior to beginning the shopping trip; the number of items planned but not purchased, operationalized as the number of items that the shopper planned to purchase prior to beginning the shopping trip but subsequently failed to purchase.

\section{Findings and Discussion}

Hypothesis 1 addresses the impact of in-store mobile technology on the effectiveness of instore communication. Shoppers using the mobile pay less attention to the shopping environment. Therefore they are less prone to marketing stimuli that are produced in store by the retailers. In particular, the number of promoted products that consumers could remember was on average 0.68 , greater for those who did not use the mobile while shopping, against 0.33 for shoppers who used the mobile during their shopping expedition (Table 4).

Furthermore, those who did not use mobile phone had a greater memory with regard to the presence of promoters inside the store ( 0.33 against 0.08 for shoppers who used the mobile, see Table 4$)$, and could therefore be more susceptible to a possible impulse buy. Conversely, those who used the mobile did not remember the presence of promoters and therefore couldn't even recall the brand or product promoted or communicated by the promoters in store with on average 0.54 product remembered against 1.60 products remembered by shoppers who did not use mobile technology in store (see Table 4).

Table 4. Impact of in-store mobile usage on the effectiveness of instore communication

\begin{tabular}{lllrrrr}
\hline & $\begin{array}{l}\text { Mobile usage during the } \\
\text { Shopping expedition }\end{array}$ & $\mathrm{N}$ & Mean & Std. Deviation & Std. Error Mean \\
\hline (a) $\begin{array}{l}\text { Can you remember some of the } \\
\text { promotional products on display in }\end{array}$ & No & Yes & 60 & $\mathbf{. 6 8}$ & .469 & .061 \\
& & 24 & $\mathbf{. 3 3}$ & .482 & .098 \\
\hline $\begin{array}{l}\text { store? } \\
\text { (b) How many items do you remember? }\end{array}$ & No & Yes & 60 & $\mathbf{1 . 6 0}$ & 1.317 & .170 \\
& & 24 & $\mathbf{. 5 4}$ & .884 & .180 \\
\hline (c) Have you noticed the presence of & No & 60 & $\mathbf{. 3 3}$ & .475 & .061 \\
& Promoters in the store? & Yes & 24 & $\mathbf{. 0 8}$ & .282 & .058 \\
\hline
\end{tabular}

(a) F=9.401 P-value=0.003; (b) F=9.401 P-value=0.003; (c) F=9.401 P-value=0.003.

According to Hypothesis 1, the recall, refer to either the promoters than the products, is much greater for those shoppers who have not used the mobile purchase during their shopping experience, so mobile devices can result in a loss of shoppers' ability to recall in-store marketing stimuli because of mobile distraction. This should be an alarm bell for the retailers, as their efforts may be ineffective. Therefore, it is necessary to seek alternative methods to capture the attention of the consumer in the store environment.

Hypotheses 2 and 3 address the impact of in-store mobile technology use on the number of unplanned purchases. In comparison to shopper not using a mobile device in-store or using a mobile device in a task-related manner, we find that consumers using mobile technology in a shopping-unrelated manner made, on average, fewer unplanned purchases (see Table 5). These results provide support for Hypothesis 2 according to the theory that mobile device use consumes attentional resources and makes in-store communication strategies, made by the retailers, less effective.

Moreover, our findings show that shoppers using a mobile device in a task-related manner made fewer purchases compared to consumers not using mobile devices (Table 5). These results provide support for Hypothesis 3 according to which shoppers using mobile device in a task-related manner make fewer unplanned purchases because they are better equipped to stay on track during the shopping trip. However, compared to consumers using mobile in a shopping unrelated manner, we find that they made more unplanned purchases due to the fact that they are able to identify more attractive alternatives for shopping. Therefore, in this case, the number of unplanned purchases is a result of a conscious decision and not a result of a mobile distraction. 
Table 5. Impact of in-store mobile usage on unplanned purchases

\begin{tabular}{llrrr}
\hline & Mobile Use & N & Mean & \multicolumn{2}{c}{ Std. Deviation } \\
\hline Unplanned Purchases & No mobile use & 60 & $\mathbf{2 . 2 2}$ & 5.352 \\
& Shopping related & 7 & $\mathbf{1 . 8 6}$ & 3.185 \\
& Shopping unrelated & 17 & $\mathbf{. 9 4}$ & 3.881 \\
\hline
\end{tabular}

$\mathrm{F}=0.439 ; \mathrm{P}$-value $=0.646$

Compared to shoppers not using mobile devices or using a mobile device in a shopping-related manner, shoppers using their smartphones in a shopping-unrelated manner failed to purchase more planned items. As shows in Table 6, they had, on average, a greater number of planned but not purchased items. These results provide support for Hypothesis 4 and specifically, using mobile technology in a manner that is unrelated to the shopping purpose increased planned but not purchased items. Therefore shopping-unrelated mobile device may contribute to missing or forgetting planned items according to the conceptualization that the distraction of unrelated-devices use can prevent shoppers' ability to recall to their mind items intended for purchases or to read items written in their shopping list. Conversely, shoppers who use the mobile device in a shopping-related manner show a marked improvement in accuracy in shopping, with a number of forgotten purchases on average close to zero. So we could state that items planned but not purchased might be a result of mobile distraction and no longer a result of a conscious decision making process.

Table 6. Impact of in-store mobile usage on planned but not purchased items

\begin{tabular}{llrrr}
\hline & Mobile Use & N & Mean & \multicolumn{2}{c}{ Std. Deviation } \\
\hline Planned but not purchased items & No mobile use & 60 & $\mathbf{. 1 7}$ & .717 \\
& Shopping related & 7 & $\mathbf{. 0 0}$ & .000 \\
& Shopping unrelated & 17 & $\mathbf{. 3 5}$ & 1.057 \\
\hline
\end{tabular}

$\mathrm{F}=0.619 ; \mathrm{P}$-value $=0.541$

These results are consistent with the conceptualization that the distraction of unrelated-device use can reduce shoppers' ability to recall or read items intended for purchase (Sciandra \& Inmann, 2014). Since these shoppers are making fewer unplanned purchases and fewer substitute item purchases, this implies that items not purchased may be a result of distraction rather than a conscious decision. This is a potential negative outcome both for consumers and retailers suggesting that shopping-unrelated mobile device may contribute to missing or forgetting planned items.

\section{Conclusions and Managerial Implications}

The role of in-store stimuli in influencing shoppers' behaviour inside the point of sales is well studied in marketing literature (Inman et al., 2009; Stilley et al., 2010; Inman \& Sciandra, 2013). Recently, many authors have increased their attention on the impact that technological distraction can have on individuals' attention towards marketing stimuli, stating the distractive nature of mobile technologies (Strayer et al., 2003; Hyman et al., 2010; Inman \& Sciandra, 2013).

Based on this framework, the main goal of our work was to investigate the influence of instore mobile use in consumer's decisions in a retail context. This topic is becoming more and more interesting because of the increasing penetration of mobile technologies. Consumers are becoming increasingly reliant on these technologies in their everyday lives (Global Mobile Consumer Survey, 2015), thus understanding the role that mobile devices play in shaping consumer decision-making in a retail context is interesting for both retailers and manufacturers.

Our findings show that shoppers using the mobile pay less attention to the shopping environment. Therefore they are less prone to instore marketing stimuli, so they make fewer unplanned purchases. The number of promoted products that consumers could remember, in fact, was greater for those who did not use the mobile while shopping comparing to shoppers who used the mobile during their shopping expedition. This could represent a new big treat for retailers and manufactures who devote many resources to the practice of shopper marketing with the aim to influence consumers along and beyond the entire path-to-purchase (Shankar, 2011). The growing penetration of digital technologies has produced significant changes in shopping habits designed to create a new scenario for shopper marketing. Today consumers enter the store much more prepared and they are able to make shopping quickly, only looking for products they had planned to buy, guided by a digital shopping list, digital coupons or printed customized promotions (Bellini et al., 2016).

The increasing penetration of mobile devices has reinforced this phenomenon, since the mobile is not used only during the shopping preparation to collect information, as shown in Bellini et al. (2016), but it could be use during the shopping expedition in store as a guide for the purchases. 
Furthermore, as emerged in our research, during the shopping expedition the mobile is frequently used for personal activities: only a small percentage of our sample $(29.2 \%)$ uses the mobile in a task-related manner. This trend makes the threats for shopper marketing activities bigger as consumers using the mobile in a task-unrelated manner are the more distracted. In-store mobile technology use has significant implications for consumers and retailers including the purchase of fewer unplanned items, failing to purchase planned items, and altering the perception of marketing stimuli produced by the retailers in store.

In line with prior research (Sciandra \& Inmann, 2014), the impact on unplanned purchases depends on the type of mobile device use on consumers decisions. We find that shoppers using mobile in a task-unrelated manner make fewer unplanned purchases compared to those using mobile in a task-related manner. While these results could appear somewhat incongruent, we argue that the higher unplanned purchases made by shopper using device in a task-related manner compared to shoppers using device in a task-unrelated manner might be a result of a conscious decision making process. For task-related mobile device use, prior research identify access to information and decision monitoring as critical factors contributing to enhanced decision-making (Sciandra \& Inmann, 2014). Therefore, shoppers may pass over a planned item and may decide to buy a product not planned before if they found it more attractive. These unplanned purchases may be attributed to enhanced decision making capabilities afforded by device use. These considerations are consistent with the literature according to which shoppers using mobile device in a task-related manner should be in a better position to manage and track their decisions. Conversely, task-unrelated device use negatively affects consumer decisions.

In line with these results, we find that task-unrelated mobile device use is positively associated with omitted items, confirming that there is a cognitive distraction hampering shoppers' ability to make decisions. Specifically, shoppers using mobile devices appear to be distracted by the mobile technology, especially who use the mobile in a shopping-unrelated manner. As a result, they forget to purchase some products they plan to buy and, above all, end up noticing much less the products displayed in store. For these subjects can be also noticed a reduced effectiveness of promotions and overall stimulus played in store.

Finally, shoppers using their mobile phone instore (regardless of their use related or unrelated to the shopping mission), are less subject to communication and to marketing stimuli produced in the retail environment. While good for consumers, as mobile devices can potentially protect them from unplanned purchases stimulated by in-store promotions, this should be a wake-up alarm for the retailer, since its efforts could also be inefficient.

Along with the reduced effectiveness of the retailers' communication, our results also suggest retailers to be careful because using a mobile device potentially results in consumers failing to purchase items that they intended to purchase and shoppers may leave planned items on the shelf and spend less overall.

The findings we summarized offer significant implications for managers. The effects of mobile device use on purchasing decisions instore are designed to create a new scenario for the practice of shopper marketing. Retailers and manufacturers have to seek for new ways to capture consumers' attention in store, conscious that consumers are becoming increasingly reliant on digital technologies and mobile device usage in the retail context will probably increase in the next years.

Considering that the more negative effects for retailers are coming from a task-unrelated manner device use (associated with the fewest unplanned purchases and the highest omitted products), managers may be able to encourage shoppers to utilize their mobile devices in a task-related ways while shopping. This might be accomplished by creating mobile application useful for reducing the negative implications related to in-store device use such as missed in-store stimuli or missed planned items.

\section{Limitations and Future Research}

While our research has valuable contributions, it also has some limitations. First, some limitations are associated with the store-intercepted survey research such as measurement error and interviewer effects. Respondents may have been influenced by the presence of interviewers and then distorted in order not to appear impulsive buyers. Another concern is about the generalizability. Our sample is too small to be considered as representative of any larger population. Some of our results sounds not significant, thus we have to extend our research, enlarging the sample and introducing new hypotheses. This study, however, wants to be a first investigation about the influence of mobile device use on shopping decisions instore. It is just a first step which will open considerable opportunity for future research.

We intend to expand our study enlarging the sample of shoppers interviewed and examining in more depth the phenomenon. In particular, we would like to better investigate the differences in shopping behavior between task-related and task-unrelated mobile device use, as Sciandra and Inman did (Sciandra \& Inman, 2014). 
Moreover, our future research will explore the influence of mobile device use on purchases at the checkout corner. This has always been recognized as the better area where stimulating impulse purchases, catching the attention of shoppers who are waiting for the checkout. The mobile device use, however, could reduce the effectiveness of the checkout in influencing unplanned purchases as consumers use the mobile in order to deceive the wait and pay less attention to the products displayed.

In the retail competitive environment, it seems that both commercial and industrial firms must compete with the mobile in order to capture the attention of consumers who are increasingly distracted. Indeed, retailers need to find new ways to establish a long lasting relationship with their customers, in order to gain a competitive advantage. A collaboration between retailers and manufactures might be the right answer for dealing with the phenomenon turning it from a threat into an opportunity.

\section{References}

Ansari, A., \& Riasi, A. (2016). Modelling and evaluating customer loyalty using neural networks: Evidence from startup insurance companies. Future Business Journal, 2(1), 15-30. https://doi.org/10.1016/j.fbj.2016.04.001

Beatty, S. E., \& Ferrell, M. E. (1998). Impulse buying: Modeling its precursors. Journal of retailing, 74(2), 169-191. https://doi.org/10.1016/S0022-4359(99)80092-X

Bell, D., Corsten, D., \& Knox, G. (2011). From point of purchase to path to purchase: How preshopping factors drive unplanned buying. Journal of Marketing, 75, 31-45. https://doi.org/10.1509/jmkg.75.1.31

Bellini, S., Cardinali, M. G., \& Grandi, B. (2016). Does shopping preparation influence consumer buying decisions? International Business Review, 9(10). https://doi.org/10.5539/ibr.v9n10p201

Bellini, S., Cardinali, M. G., \& Grandi, B. (2017). A structural equation model of impulse buying behaviour in grocery retailing. Journal of Consumers and Retailing Services, forthcoming. https://doi.org/10.1016/j.jretconser.2017.02.001

Block, L., \& Morwitz, V. (1999). Shopping list as an external memory aid for grocery shopping: Influences on list writing and list fulfillment. Journal of Consumer Psychology, 8(4), 343-375. https://doi.org/10.1207/s15327663jcp0804_01

Briem, V., \& Hedman, L. R. (1995). Behavioural effects of mobile telephone use during simulated driving. Ergonomics, 38(12), 2536-2562. https://doi.org/10.1080/00140139508925285

Broadbent, D. E. (1958). Perception and communication. London, UK: Perfamon Press. https://doi.org/10.1037/10037-000

Brookhuis, K. A., De Vries, G., \& De Waard, D. (1991). The effects of mobile telephoning on driving performance. Accident Analysis and Prevention, 23(4), 309-316. https://doi.org/10.1016/0001-4575(91)90008-S

Bucklin, R. E., \& Lattin, J. M. (1991). A two-state model of purchase incidence and brand choice. Marketing Science, 10(1), 24-39. https://doi.org/10.1287/mksc.10.1.24

Cheema, A., \& Soman, D. (2006). Malleable mental accounting: The effect of flexibility on the justification of attractive spending and consumption decision. Journal of Consumer Psychology, 16(1), 33-44. https://doi.org/10.1207/s15327663jcp1601_6

Donovan, R., Rossiter, J., Marcoolyn, G., \& Nesdale, A. (1994). Store atmosphere and purchasing behavior. Journal of Retailing, 70(3), 283-294. https://doi.org/10.1016/0022-4359(94)90037-X

Drews, F. A., Pasupathi, M., \& Strayer, D. L. (2008). Passenger and cell phone conversations in simulated driving. Journal of Experimental Psychology, 14(4), 392-400. https://doi.org/10.1037/a0013119

Fagot, C., \& Pashler, H. (1992). Making two responses to a single object: Implications for the central attentional bottleneck. Journal of Experimental Psychology: Human Perception and Performance, 18(4), 1058-1079. https://doi.org/10.1037/0096-1523.18.4.1058

Global Mobile Consumer Survey. (2015).

Häubl, G., \& Trifts, V. (2000). Consumer decision making in online shopping environments: The effects of interactive decision aids. Marketing science, 19(1), 4-21. https://doi.org/10.1287/mksc.19.1.4.15178

Hirschman, E. C., \& Holbrook, M. B. (1982). Hedonic consumption: Emerging concepts, methods and propositions. The Journal of Marketing, 92-101. https://doi.org/10.2307/1251707 
Hoch, S., \& Loewenstein, J. (1991). Time-inconsistent preferences and consumer self-control. Journal of Consumer Research, 17(4), 492-507. https://doi.org/10.1086/208573

Hyman, Ira E., Boss S. M., Wise, B. M., McKenzie, K. E., \& Caggiano, J. M. (2010). Did you see the unicycling clown? Inattentional blindness while walking and talking on a cell phone. Applied Cognitive Psychology, 34(5), 598-607. https://doi.org/10.1002/acp.1638

Inman J. J., Winer, R. S., \& Ferraro, R. (2009). The interplay among category characteristics, customer characteristics, and customer activities on in-store decision making. Journal of Marketing, 73(5), 19-29. https://doi.org/10.1509/jmkg.73.5.19

Inman, J., \& Sciandra, M. (2013). Smart phones, bad decisions? The impact of in-store mobile technology use on consumer decisions. In NA - Advances in Consumer Research, 41.

Iyer, E. (1989). Unplanned purchasing: Knowledge of shopping environment and time pressure. Journal of Retailing, 65(1), 40-57.

Iyer, E., \& Ahlawat, S. (1987). Deviation from a shopping plan: When and why do consumers not buy items as planned. Advances in Consumer Research, 14, 246-250.

Kahneman, D. (1973). Attention and Effort. Englewood Cliffs, NJ: Prentice Hall. Keaveney, Susan.

Kollat, D., \& Willett, R. (1967). Customer impulse purchasing behavior. Journal of Marketing Research, 4, 21-31. https://doi.org/10.2307/3150160

Lavie, N. (2005). Distracted and confused?: Selective attention under load. Trends in Cognitive Sciences, 9(2), 75-82. https://doi.org/10.1016/j.tics.2004.12.004

Lavie, N., Hirst, A., De Fockert, J. W., \& Viding, E. (2004). Load theory of selective attention and cognitive control. Journal of Experimental Psychology, 133(3), 339-454. https://doi.org/10.1037/0096-3445.133.3.339

Mohan, G., Sivakumaran, B., \& Sharma, P. (2013). Impact of store environment on impulse buying behavior. European Journal of Marketing, 47(10), 1711-1732. https://doi.org/10.1108/EJM-03-2011-0110

Murray, K. B., \& Häubl, G. (2008). Interactive consumer decision aids. In B. Wierenga, Handbook of Marketing Decision Models. New York, NY: Springer Science \& Business Media, LLC. https://doi.org/10.1007/978-0-387-78213-3_3

Navon, D., \& Gopher, D. (1980). Task difficulty, resources, and dual-task performance. Attention and Performance, R. S. Nickerson, Vol. 8. Hillsdale, NJ.

Norman, D. A., \& Bobrow, D. G. (1975). On data-limited and resource-limited processes. Cognitive Psychology, 7(1), 44-64. https://doi.org/10.1016/0010-0285(75)90004-3

Pashler, H., \& Johnston, J. C. (1998). Attentional limitations in dual-task performance. Attention, Harold Pashler, ed. East Sussex, UK: Psychological Press Ltd.

Puccinelli, N., Goodstein, R., Grewal, D., Price, R., Raghubir, P., \& Stewart, D. (2009). Customer experience management in retailing: Understanding the buying process. Journal of Retailing, 85(1), 15-30. https://doi.org/10.1016/j.jretai.2008.11.003

Riasi, A., \& Pourmiri, S. (2015). Effects of online marketing on Iranian ecotourism industry: Economic, sociological, and cultural aspects. Management Science Letters, 5(10), 915-926. https://doi.org/10.5267/j.msl.2015.8.005

Sciandra, M. R. (2014). Communication breakdown? Essays examining attention and distraction in technology mediated consumer communications. Working Paper, University of Pittsburgh.

Sciandra, M. R., \& Inman, J. J. (2014). Digital distraction: Consumer mobile device use and decision making. Working Paper, University of Pittsburgh.

Shankar, V. (2014). Shopper marketing 2.0: Opportunities and challenges. Review of Marketing Research, 11, 189-208. https://doi.org/10.1108/S1548-643520140000011007

Sharma, P., Sivakumaran, B., \& Marshall, R. (2010). Impulse buying and variety seeking: A trait- correlates perspective. Journal of Business Research, 63(3), 276-283. https://doi.org/10.1016/j.jbusres.2009.03.013

Silveria, P., \& Marreiros, C. (2014). Shopper marketing: A literature review. International Review of Management and Marketing. 4(1), 90-97. 
Stilley, Karen, M., Inman, J. J., \& Wakefield, K. L. (2010). Spending on the fly: Mental budgets, promotions, and spending behavior. Journal of Marketing, 74(3), 34-47. https://doi.org/10.1509/jmkg.74.3.34

Strayer, D. L., \& Johnston, W. A. (2001). Driven to distraction: Dual-task studies of simulated driving and conversing on a cellular phone. Psychological Science, 12(6), 462-466.

https://doi.org/10.1111/1467-9280.00386

Strayer, D. L., Drews, F. A., \& Johnston, W. A. (2003). Cell phone induced failures of visual attention during simulated driving. Journal of Experimental Psychology, 9(1), 23-32. https://doi.org/10.1037/1076-898x.9.1.23

Welford, \& Traviss, A. (1952). The psychological refractory period and the timing of high-speed performance - A review and a theory. British Journal of Psychology, 43(1), 2-19.

https://doi.org/10.1111/j.2044-8295.1952.tb00322.x

\section{Copyrights}

Copyright for this article is retained by the author(s), with first publication rights granted to the journal.

This is an open-access article distributed under the terms and conditions of the Creative Commons Attribution license (http://creativecommons.org/licenses/by/4.0/). 